\title{
PENGARUH EKSTRAK DAUN BUNGUR (LAGERSTROEMIA SPECIOSA) TERHADAP PENURUNAN KADAR GLUKOSA DARAH PADA TIKUS PUTIH STRAIN WISTAR
}

\author{
Tania Widya Ekayanti ${ }^{1}$, Bragastio ${ }^{2}$, Abi Noer Wahyono ${ }^{3}$ \\ Fakultas Kedokteran Universitas Muhammadiyah Malang, J1. Bendungan Sutami No.188A, Kota Malang, \\ 65145, Indonesia 0341-551149
}

\begin{abstract}
ABSTRAK
Pengaruh Ekstrak Daun Bungur (Lagerstroemia speciosa) terhadap Penurunan Glukosa Darah pada Tikus Putih Strain Wistar. Latar Belakang: Jumlah penderita diabetes melitus di Indonesia mengalami peningkatan yang nyata. Saat ini berkembang pengobatan dengan bahan-bahan alam salah satunya daun bungur. Daun bungur mengandung asam karosolik dan ellagitanins yang dapat menurunkan kadar glukosa darah pada penderita diabetes. Tujuan : Membuktikan pengaruh ekstrak daun bungur (Lagerstroemia speciosa) terhadap penurunan kadar glukosa darah pada tikus putih strain wistar yang diinduksi dengan streptozotocin dan nikotinamide. Metode : True experimental, dengan rancangan The pre post test Control Group Design. Sampel tikus putih strain wistar yang dibagi 3 kelompok. I: kontrol positif hanya injeksi Streptozotocin dan Nikotinamide, II: diberi Streptozotocin dan Nikotinamide dan ekstrak daun bungur (Lagerstroemia speciosa) 0,3 mg/150 gr BB/hari, dan III: diberi Streptozotocin dan Nikotinamide dan ekstrak daun bungur (Lagerstroemia speciosa) 1,5 mg/150 gr BB/hari. Analisis data menggunakan One way Anova dan uji regresi linier. Hasil Penelitian dan Diskusi : Dari hasil One Way Anova didapatkan pengaruh yang bermakna antar kelompok perlakuan. Hasil uji Tukey 5\%, menunjukan notasi yang berbeda pada kelompok I, II, III yang artinya tiap-tiap kelompok memiliki perubahan kadar glukosa darah yang berbeda satu sama lain. Hasil uji korelasi didapatkan nilai pearson correlation $=0,914$. Hasil uji regresi didapatkan $\mathrm{R}^{2}=0,835$. Kesimpulan : Pemberian ekstrak daun bungur (Lagerstroemia speciosa) berpengaruh terhadap penurunan kadar glukosa darah..
\end{abstract}

\section{ABSTRACT}

The Effect of Bungur Leaves Extract (Langerstroemia speciosa) to Decrease the Blood Glucose Level of White Rats Strain Wistar. Background: The number of diabetes mellitus patients in Indonesia has noticeable increase. Nowadays, the treatment using herbal materials is developing, one of them is bungur leaf. Bungur leaf contains carosolic acid and ellagitanis that are able to decrease the blood glucose level in diabetic patients.Objective : Proved the effect of Bungur leaf extract (Lagerstroemia speciosa) to decrease blood glucose level of white rats strain wistar that induced by streptozotocin and nikotinamide.Method: True experiment with The Pre Post Control Group Design. The strain wistar samples were divided into 3 groups. Group I: positive control with streptozotocin and nikotinamide injection, group II: injected streptozotocin and nikotinamide and 0,3 mg/150 gr bw/day bungur leaf extract, and group III: injected with streptozotocin and nikotinamide and 1,5 mg/150 gr bw/day bungur leaf extract. Data were analyzed by one way Anova and linier regression test. Result and Discussion: One way Anova test showed significant effect among treatment group. The 5\% tukey test result showed there was different notation from each groups which meant each group had the differences at blood glucose level. Correlation test showed pearsons correlation $=$ 0,914. Regression test showed $\mathrm{R}^{2}=0,835$ Conclussion : Bungur leaf extract (Lagerstroemia speciosa) administration influences the lowering of blood glucose level.

Key words : bungur leaf extract (Lagerstroemia speciosa), carosolic acid, blood glucose, streptozotocin and nikotinamide

\section{PENDAHULUAN}

Diabetes mellitus (DM) merupakan masalah kesehatan yang utama diseluruh dunia. DM menempati urutan keempat penyebab kematian terbanyak diseluruh dunia. Penderita diabetes meningkat dengan cepat diseluruh dunia, terutama di negara yang sedang berkembang. (Hossain, 2007). World health organization (WHO) memperkirakan pada tahun 1995 Indonesia menempati urutan ke-7 pengidap DM terbanyak dengan jumlah penderita sebanyak 4,5 juta dan pada tahun 2025 Indonesia diperkirakan akan menduduki peringkat ke-5 pengidap diabetes terbanyak dengan jumlah penderita sebanyak 12,4 juta (Suyono, 2007).
Diabetes dapat menyebabkan komplikasi jangka panjang, yang dapat melibatkan jantung, ginjal, mata, saraf, dan pembuluh darah. Kepatuhan penderita yang kurang terhadap pengobatan, tingginya biaya pengobatan, dan gaya hidup yang tidak sehat menyebabkan diabetes mellitus sulit terkendali (Misnadiarly, 2006).

Semakin berkembangnya ilmu pengetahuan dan tekhnologi, pengobatan dengan menggunakan bahan-bahan alam banyak dikembangkan. Hal ini terjadi karena semakin banyaknya ditemukan fakta baru bahwa tidak sedikit dari bahan-bahan yang diteliti dan telah dikonsumsi secara umum 
dari penemuan-penemuan terdahulu memberikan manfaat pada kehidupan manusia khususnya dibidang kesehatan (Rohdian, 2009). Bungur banyak tumbuh di hutan-hutan di pulau Jawa dan Sumatera. Tanaman bungur dapat tumbuh hingga ketinggian 800 meter di atas permukaan laut. Bungur dapat tumbuh di daerah yang tergenang air ataupun daerah yang bertanah gersang (Suradji, 2009). Bahan aktif yang terkandung di dalam daun bungur berupa asam karosolik, dimana bahan tersebut memiliki khasiat meningkatkan translokasi GLUT 4 (Keawpradub, 2009). Asam karosolik tersebut mengaktifasi proses transfer glukosa darah ke dalam sel sehingga kadar glukosa darah turun, sehingga penumpukan glukosa dalam darah dapat dicegah (Untung, 2010).

Tujuan secara umum pada penelitian ini adalah untuk membuktikan pengaruh ekstrak daun bungur (Lagerstroemia speciosa) terhadap penurunan kadar glukosa darah pada tikus putih strain wistar yang diinduksi dengan streptozotocin dan nikotinamide. Sedangkan tujuan khususnya yaitu membuktikan pengaruh ekstrak daun bungur pada dosis 2 $\mathrm{mg} / \mathrm{kg} \mathrm{BB}$ dan $10 \mathrm{mg} / \mathrm{kg}$ BB terhadap penurunan glukosa darah tikus putih dan membuktikan hubungan dosis ekstrak daun bungur terhadap penurunan kadar glukosa darah Sedangkan untuk manfaat dari penelitian ini adalah untuk menambah wawasan ilmu pengetahuan dibidang kesehatan, terutama tentang pengobatan dengan herbal, dan dapat memberikan informasi ilmiah tentang obat tradisional yakni daun bungur (Lagerstroemia speciosa) dalam menurunkan kadar glukosa darah tikus putih yang diinduksi dengan streptozotocin dan nikotinamide. Bagi para klinisi penelitian ini juga dapat berkontribusi dalam upaya menurunkan kadar glukosa darah pada diabetes tipe 2 dengan pengobatan herbal.

\section{METODE}

\section{Lokasi Penelitian}

Penelitian ini akan dilaksanakan selama 1 bulan bertempat di Laboratorium Kimia Universitas Muhammadiyah Malang.

\section{Alat dan Bahan}

Alat yang digunakan antara lain timbangan untuk menimbang berat badan tikus, alat pemeliharaan tikus (bak tikus, kandang dan penutup kandang dari anyaman kawat, tempat makan dan minum, sekam), gelas ukur, alat untuk mengukur glukosa darah tikus dengan metode GOD-PAP, botol ekstrak daun bungur, sonde modifikasi.

Bahan yang digunakan yaitu tikus, makanan tikus, pengukuran variable, streptozotocin (STZ) dan nikotinamide, daun bungur, $\mathrm{NaCl} 0,9 \%$, reagen, aquades, serum darah tikus.

\section{Dosis Aquades}

Aquades yang diberikan pada semua tikus adalah $2 \mathrm{ml} /$ 200 gram BB.

\section{Dosis Nikotinamide}

Dosis nikotinamide yang disuntikan adalah $240 \mathrm{mg} /$ $\mathrm{kg}$ BB dengan volume pelarut PBS sebanyak $0,5 \mathrm{ml}$ per ekor hewan coba (Barik et al, 2008).

\section{Dosis Streptozotocin}

STZ diberikan secar intraperitonial dengan dosis $100 \mathrm{mg} / \mathrm{kg}$ BB pada tikus. Serbuk STZ dilarutkan dalam dapar sitrat. Dosis yang digunakan pada penelitian ini adalah $15 \mathrm{mg}$

\section{Dosis Ekstrak Daun Bungur}

Ekstrak daun bungur yang efektif untuk menurunkan kadar glukosa darah adalah $2 \mathrm{mg} / \mathrm{kg}$ BB dan $10 \mathrm{mg} / \mathrm{kg}$ BB (Oliff, 2011). Ekstrak daun bungur yang diberikan pada percobaan ini adalah $0,3 \mathrm{mg}$ dan $1,5 \mathrm{mg}$.

\section{Penyiapan Larutan Uji}

Serbuk nikotinamide dilarutkan dalam PBS (phosphate buffered saline) sebelum disuntikan ke hewan coba (Fordous et al,2009). Kemudian serbuk STZ sebanyak $400 \mathrm{mg}$ dilarutkan dengan dapar sitrat. Larutan dapat sitrat merupakan kombinasi antara dinatrium sitrat (asam sitrat monohidrat dan $\mathrm{NaOH} 1 \mathrm{M}$ ) dengan volume 53,2 mL serta penambahan larutan $\mathrm{NaOH} 1 \mathrm{M}$ sehingga larutan tepat $100 \mathrm{~mL}$. Dosis STZ yang diberikan pada tikus adalah $3,75 \mathrm{ml}$ dibagi dalam 7 hari. Setelah itu ekstrak daun bungur diberikan sesuai dengan dosis masing-masing kelompok.

\section{Pembuatan Ekstrak Daun Bungur}

Daun bungur dikeringkan dalam oven dengan suhu 45?C sampai benar-benar kering. Daun yang sudah kering kemudian ditumbuk sehingga didapatkan $500 \mathrm{mg}$ bubuk daun bungur. Bubuk daun bungur kemudian dimaserasi dalam $1500 \mathrm{ml}$ methanol selama 30 menit kemudian disaring, hasil saringan kemudian diletakkan di dalam botol tertutup untuk mengurangi penguapan. Hal tersebut dilakukan berulang-ulang sebanyak 3 kali. Hasil ekstraksi kemudian di letakkan di dalam botol tertutup kemudian dilakukan evaporasi agar didapatkan ekstrak yang murni (Keawpradub, 2009).

Ekstrak yang di dapat kemudian dibagi sesuai dengan dosis untuk masing-masing tikus, yaitu dosis I: 0,3 mg/ ekor/hari dan dosis II: $1,5 \mathrm{mg} /$ ekor/hari. Sebelum diberikan pada tikus ekstrak tersebut di larutkan dalam aquades $2 \mathrm{ml}$. Ekstrak daun bungur diberikan dengan menggunakan sonde.

\section{Analisis Data}

Parameter yang digunakan adalah penurunan kadar glukosa darah setelah pemberian ekstrak daun bungur selama 2 minggu (hari ke-15 sampai hari ke 28) pada kelompok III dan IV, yang sebelumnya diinduksi dengan streptozotocin dan nikotinamid selama satu minggu. Penurunan kadar glukosa darah dianalisis dengan uji One Way ANOVA pada tingkat kepercayaan 95\%.

Kemudian dilanjutkan dengan uji regresi untuk mengetahui adatidaknya hubungan dosis ekstrak daun bungur dengan respon (kadar gula darah) dan mengetahui seberapa kuat hubungan tersebut.

\section{HASIL DAN PEMBAHASAN}

Hasil penelitian menunjukan pada tabel 1 dimana kelompok I (kelompok kontrol positif) memiliki perubahan kadar glukosa darah sesaat paling rendah, yaitu sebesar 1,88 
$\mathrm{mg} /$ dl.. Pada kelompok II setelah pemberian ekstrak daun bungur dengan dosis $0,3 \mathrm{mg} / 150 \mathrm{gr} \mathrm{BB} /$ hari didapatkan perubahan kadar glukosa darah sesaat yang lebih besar dari kelompok I. Pada kelompok III yang mendapatkan ekstrak daun bungur dengan dosis 1,5 mg/ 150 gr BB/hari didapatkan perubahan kadar glukosa darah sesaat yang paling besar, yaitu sebesar $87,63 \mathrm{mg} / \mathrm{dl}$. Hasil tersebut menunjukan adanya hubungan yang kuat, yaitu pemberian ekstrak daun bungur berpengaruh terhadap penurunan kadar glukosa darah tikus putih yang diinduksi dengan STZ dan nikotinamide.
Hewan coba yang diinduksi dengan STZ akan mengalami gangguan respon terhadap glukosa dan sensitivitas sel $\beta$ terhadap glukosa. STZ pada hewan coba secara selektif bekerja pada sel $\beta$ pankreas yang bertanggung jawab untuk memproduksi insulin, sedangkan sel á dan $\beta$ tidak dipengaruhi secara signifikan oleh pemberian STZ (Szkudelski, 2001). Induksi STZ dapat pula menyebabkan GLUT 4 yang memfasilitasi masuknya glukosa ke dalam otot menurun. Hal tersebut menyebabkan penurunan pemasukan glukosa ke dalam otot dan jaringan adiposa, sehingga menyebabkan kadar glukosa darah meningkat (Rees, 2005).

Tabel 1. Rerata Glukosa Darah Sesaat Tikus Putih

\begin{tabular}{c|c|c|c|c}
\hline \multirow{2}{*}{ Perlakuan } & \multicolumn{4}{|c}{ Rerata Glukosa Darah Sesaat (mg/d1) } \\
\cline { 2 - 5 } & Awal perlakuan & $\begin{array}{c}\text { Injeksi STZ dan } \\
\text { Nikotinamide }\end{array}$ & Akhir Perlakuan & $\begin{array}{c}\text { Perubahan } \\
\text { Glukosa Darah }\end{array}$ \\
\hline K I & $\backslash 114,34 \pm 4,36$ & $215,27 \pm 5,75$ & $213,39 \pm 6,05$ & $1,88 \pm 1,70$ \\
\hline K II & $114,84 \pm 5,68$ & $218,49 \pm 8,20$ & $172,87 \pm 7,69$ & $45,62 \pm 3,55$ \\
\hline K III & $116,80 \pm 8,10$ & $215,04 \pm 9,45$ & $127,40 \pm 8,21$ & $87,63 \pm 15,28$ \\
\hline
\end{tabular}

Pemberian nikotinamide yang merupakan bentuk vitamin B3 dapat mempertahankan dan meningkatkan fungsi sel â pankreas. Nikotinamide dapat mencegah makrofag yang menginduksi kerusakan sel â pankreas (Passero, 2011). Induksi hewan coba dengan STZ dan nikotinamide menyebabkan terjadi resistensi insulin dan penurunan GLUT 4, sehingga yang terjadi adalah DM tipe II. Penurunan kadar glukosa darah pada hewan coba setelah diberikan ekstrak daun bungur terjadi karena daun bungur mengandung asam karosolik dan ellagitanin yang berfungsi menginduksi translokasi GLUT 4 yang berfungsi memfasilitasi masuknya glukosa ke dalam sel. Selain itu asam karosolik juga menstimulasi uptake glukosa dengan cara meningkatkan fosforilasi reseptor insulin. Dengan adanya mekanisme tersebut maka peningkatan kadar glukosa dalam darah dapat dicegah (Park, 2011).

Berdasarkan hasil penelitian didapatkan bahwa kelompok yang mendapatkan ekstrak daun bungur yaitu kelompok KII dan KIII mengalami penurunan kadar glukosa darah. Hal tersebut sesuai dengan penelitian sebelumnya yang dilakukan oleh Park (2011) yang menyatakan bahwa pemberian ekstrak daun bungur dengan dosis 10 $\mathrm{mg} / \mathrm{kg} \mathrm{BB}$ pada tikus dengan DM tipe 2 selama 2 minggu menunjukan penurunan kadar glukosa darah yang signifikan. Penelitian yang dilakukan oleh Saha (2009) juga menunjukan bahwa pemberian ekstrak daun bungur dengan dosis $2 \mathrm{mg} /$ $\mathrm{kg}$ BB pada tikus dengan DM tipe 2 menunjukan penurunan kadar glukosa darah yang signifikan.

Berdasarkan uji regresi didapatkan nilai determinasi $\mathrm{R}^{2}$ $=0,835$, yang artinya pengaruh daun bungur dalam penurunan kadar glukosa darah adalah sebesar 83,5\%. Penurunan kadar glukosa darah 16,5\% sisanya dipengaruhi oleh keadaan tikus putih itu sendiri, yaitu gerakannya yang aktif. Selama kerja fisik sedang atau berat terjadi penggunaan glukosa, dimana pengggunaan glukosa tersebut tidak membutuhkan sejumlah besar insulin. Hal tersebut disebabkan serabut otot yang bekerja menjadi permeabel terhadap glukosa bahkan tanpa adanya insulin akibat proses kerja itu sendiri (Guyton, 2008).
Berdasarkan fakta yang ditemukan dalam penelitian ini dan melalui kajian statistika maka dapat disimpulkan bahwa hipotesis tentang pengaruh pemberian ekstrak daun bungur terhadap penurunan kadar glukosa darah tikus putih strain wistar terbukti. Namun demikian penelitian ini belum sempurna karena dalam penelitian ini tidak dapat menunjukan variasi dosis daun bungur dalam menurunkan kadar glukosa darah serta besar dosis ekstrak daun bungur yang berpotensi menyebabkan efek samping hipoglikemia dan toksik terhadap organ lain. Penelitian ini juga belum dapat menunjukan efek pada pengunaan daun bungur dalam jangka panjang. Dengan demikian diperlukan penelitian lebih lanjut.

\section{SIMPULAN}

Berdasarkan hasil dan pembahasan dalam penelitian ini, maka dapat ditarik kesimpulan pemberian ekstrak daun bungur (Lagerstroemia speciosa) dengan dosis $2 \mathrm{mg} / \mathrm{kg}$ BB dan $10 \mathrm{mg} / \mathrm{kg}$ BB berpengaruh terhadap penurunan kadar glukosa darah tikus putih. Semakin besar dosis ekstrak daun bungur maka penurunan kadar glukosa darah semakin besar.

\section{DAFTAR PUSTAKA}

Alvin P, 2008, Diabetes Mellitus, In: Harrison's Principle of Internal Medicine, 17th Edition, McGraw-Hill Companies, USA, pp. 2275-2304.

Barik R, Jain S, Qwarta D, Jastri A, Tripatri G S, Gayal R, 2008, Antidiabetic Activity of Aqueous Root Extract of Ichnocarpus frutecens in STZ-Nikotinamide Induced Type II Diabetic in Rats, Indian Journal of Pharmacology, 40, pp 19-22.

Bilous RW, 2002, Bimbingan Dokter Pada Diabetes, Dian Rakyat, Jakarta, pp. 40-46.

Deocoris CC, Aguinaldo RR, Asencion AS, 2005, Hypoglycemic Activity of Irradiated Banaba Leaves, Journal of Applied Sciencse Research, 1, pp. 95-98. 
Firdous MR, Koneri CH, Sarvaradu M, Harish K.H, Shubhapriya, 2009, NIDDM Antidiabetic Activity of saponins of Momordica cymbalaria in Streptozotocin-Nikotinamide Departement of Pharmacology, R R College of Pharmacy, Bangalore, India,3, pp. 1460-1465.

Guyton AC, Hall JE, 2008, Insulin Glukagon dan Diabetes Melitus, dalam Buku Ajar Fisiologi Kedokteran, Edisi 11, Penerbit Buku Kedokteran EGC, Jakarta, pp. 1010-1028.

Katzung BG, 2002, Farmakologi Dasar dan Klinik Buku 2, Edisi 8, Salemba Medika, Jakarta, pp. 481-495.

Keawpradub N, Purintrapiban J, 2009, Upregulation of Glucose Uptake in L8 Myotubes by The Extract From Lagerstroemia speciousa: a Possible Mechanism of Action, Maejo International Journal of Science and Technology, 3(03), pp. 472-485.

Kishore P, 2008, Diabetes Mellitus, viewed 24 january 2011, $<$ http//merckmanuals.com/home/hormonal and matabolic disorder/diabetes mellitus $\mathrm{dm} /$ diabetes mellitus. html>

Lenzen S, 2008, Review: The mechanisms of alloxan-and streptozotocin-induced Diabetes, Diabetologi, 51, pp. 216-226.

Misnadiarly, 2006, Diabetes Melitus: Menanggulangi dan Mencegah Komplikasi, Edisi I, Pustaka Populer, Jakarta.

Murray RK, Granner DK, Mayes PA, Rodwel VW, 2003, Harper Biochemistry. 25th Edition, diterjemahkan : Hartono A dalam Biokimia Harper EGC, Jakarta, pp. 195-205.

Ollif HS, 2006, Corosolic Acid Effects on Plasma Glucose Levels, Diabetes Clinical Practise, 73 (2), pp. 174-177.

Pandelaki K, 2007, Retinopati Diabetik, dalam Buku Ajar Ilmu Penyakit Dalam, Jilid III Edisi IV, Pusat Penerbitan Departemen Ilmu Penyakit Dalam Fakultas Kedokteran Universitas Indonesia, Jakarta, pp. 18891893.

Park C, Lee J, 2011, Banaba: The Natural Remedy as Antidiabetic Drug, Biomedical Research, 22 (2), pp. 125-129.

Passero K, 2011, NADH Supplements and Information, viewed 30 januari 2011, <http//nutrasanus.com/ nadh.html>

Pinoyfarmer, 2010, Medical Plants: Banaba, viewed 25 April 2011, <http//agripinoy.net/ Medical Plants: Banaba>.

Price SA, Wilson LM, 2006, Patofisiologi volume 2, Edisi 6, EGC, Jakarta.

Rees DA, Alcolado JC, 2005, Animal models od diabetes mellitus, Diabetic Medicine, 22, pp. 359-370.

Rohdiana D, 2009, Teh Ini Menyehatkan, Alfabeta, Bandung.

Saha KB, Bhuiyan NH, Mazumder K, Haque F, 2009, Hypoglycemic activity of Lagerstroemia speciosa extract on streptozotocin induced diabetic rat: Underlying mechanism of action, Journal of the Bangladesh Pharmacological Society, 4, pp. 79-83.

Silbernagl S, Lang F, 2007, Teks dan Atlas Berwarna Patofisiologi, EGC, Jakarta.

Suherman SK, 2007, Insulin dan Antidiabetik Oral, dalam
Farmakologi dan Terapi, Edisi 5, Balai Penerbit FKUI, Jakarta, pp. 481-485.

Supranto J, 2007, Teknik Sampling Survey \& Eksperimen, Rineka Cipta, Jakarta.

Suradji, Sarah M, 2009, Bungur (Lagerstroemia speciosa), viewed 25 April 2011, <http//bptphbalinusra.net/203bungur.html>

Suyono S, 2007, Diabetes Melitus di Indonesia, dalam Buku Ajar Ilmu Penyakit Dalam, Jilid III Edisi IV, Pusat Penerbitan Departemen Ilmu Penyakit Dalam Fakultas Kedokteran Universitas Indonesia, Jakarta, pp. 1852-1856.

Szkudelski T, 2001, The mechanism of alloxan and streptozotocin action in b cells of the rat pancreas, Physiol Res, 50, pp. 537-546.

Tedjapranata M, 2009, Diabetes Melitus, viewed 24 january 2011, <http//gbimawarsaron/DiabetesMelitus>

Tjay TH, Rahardja K, 2002, Obat-obat Penting, Elex Media Komputindo, Jakarta.

Untung O, 2010, Herbal Indonesia Berkhasiat, Vol. 08, Trubus, Depok.

Waspadji S, 2007, Komplikasi Kronik Diabetes: Mekanisme Terjadinya Diagnosis dan Strategi pengelolaan, dalam Buku Ajar Ilmu Penyakit

Dalam Jilid 3, Edisi IV, Pusat Penerbitan Departemen Ilmu Penyakit Dalam FKUI, Jakarta, pp. 1884-1888.

Wheteril D, Keriakes D, 2001, Seri Kesehatan: Diabetes, PT. Elex Komputindo Kelompok Gramedia, Jakarta. 